\title{
Front Matter: Volume 8997
}

, "Front Matter: Volume 8997," Proc. SPIE 8997, Advances in Photonics of Quantum Computing, Memory, and Communication VII, 899701 (26 March 2014); doi: $10.1117 / 12.2063507$

SPIE. Event: SPIE OPTO, 2014, San Francisco, California, United States 


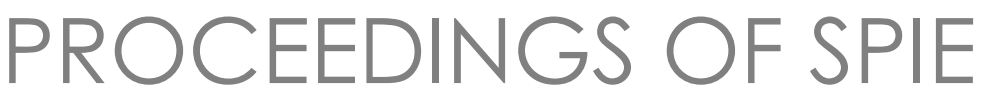

\section{Advances in Photonics of Quantum Computing, Memory, and Communication VII}

Zameer U. Hasan

Philip R. Hemmer

Hwang Lee

Charles M. Santori

Editors

4-6 February 2014

San Francisco, California, United States

Sponsored and Published by

SPIE 
The papers included in this volume were part of the technical conference cited on the cover and title page. Papers were selected and subject to review by the editors and conference program committee. Some conference presentations may not be available for publication. The papers published in these proceedings reflect the work and thoughts of the authors and are published herein as submitted. The publisher is not responsible for the validity of the information or for any outcomes resulting from reliance thereon.

Please use the following format to cite material from this book:

Author(s), "Title of Paper," in Advances in Photonics of Quantum Computing, Memory, and Communication VII, edited by Zameer U. Hasan, Philip R. Hemmer, Hwang Lee, Charles M. Santori, Proceedings of SPIE Vol. 8997 (SPIE, Bellingham, WA, 2014) Article CID Number.

ISSN: 0277-786X

ISBN: 9780819499103

Published by

SPIE

P.O. Box 10, Bellingham, Washington 98227-0010 USA

Telephone +1 3606763290 (Pacific Time) · Fax +1 3606471445

SPIE.org

Copyright (c) 2014, Society of Photo-Optical Instrumentation Engineers.

Copying of material in this book for internal or personal use, or for the internal or personal use of specific clients, beyond the fair use provisions granted by the U.S. Copyright Law is authorized by SPIE subject to payment of copying fees. The Transactional Reporting Service base fee for this volume is $\$ 18.00$ per article (or portion thereof), which should be paid directly to the Copyright Clearance Center (CCC), 222 Rosewood Drive, Danvers, MA 01923. Payment may also be made electronically through CCC Online at copyright.com. Other copying for republication, resale, advertising or promotion, or any form of systematic or multiple reproduction of any material in this book is prohibited except with permission in writing from the publisher. The CCC fee code is 0277-786X/14/\$18.00.

Printed in the United States of America.

Publication of record for individual papers is online in the SPIE Digital Library.

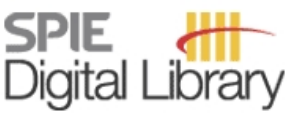

SPIEDigitalLibrary.org

Paper Numbering: Proceedings of SPIE follow an e-First publication model, with papers published first online and then in print and on CD-ROM. Papers are published as they are submitted and meet publication criteria. A unique, consistent, permanent citation identifier (CID) number is assigned to each article at the time of the first publication. Utilization of CIDs allows articles to be fully citable as soon as they are published online, and connects the same identifier to all online, print, and electronic versions of the publication. SPIE uses a six-digit CID article numbering system in which:

- The first four digits correspond to the SPIE volume number.

- The last two digits indicate publication order within the volume using a Base 36 numbering

system employing both numerals and letters. These two-number sets start with 00, 01, 02, 03, 04, $05,06,07,08,09,0 A, 0 B \ldots$. 0Z, followed by 10-1Z, 20-2Z, etc.

The CID Number appears on each page of the manuscript. The complete citation is used on the first page, and an abbreviated version on subsequent pages. Numbers in the index correspond to the last two digits of the six-digit CID Number. 


\section{Contents}

vii Conference Committee

DIAMOND NANOPHOTONICS II: JOINT SESSION WITH CONFERENCE 8994

899702 Fabrication of GaP disk resonator arrays coupled to nitrogen-vacancy centers in diamond [8997-1]

N. K. Thomas, R. Barbour, Univ. of Washington (United States); Y. Song, M. L. Lee, Yale Univ. (United States); K.-M. C. Fu, Univ. of Washington (United States)

\section{QUANTUM COMMUNICATION AND QUANTUM COMPUTING WITH PHOTONS I}

899707 Evaluation of the phase correlation between the optical pulses for transmission in quantum key distribution [8997-6]

T. Kobayashi, A. Tomita, A. Okamoto, Hokkaido Univ. (Japan)

899709 High-speed bridge circuit for InGaAs avalanche photodiode single-photon detector [8997-8]

H. Hashimoto, A. Tomita, A. Okamoto, Hokkaido Univ. (Japan)

8997 OA QEYSSAT: a mission proposal for a quantum receiver in space (Invited Paper) [8997-9] T. Jennewein, Univ. of Waterloo (Canada); J. P. Bourgoin, COM DEV Canada (Canada); B. Higgins, C. Holloway, E. Meyer-Scott, Univ. of Waterloo (Canada); C. Erven, Univ. of Waterloo (Canada) and Univ. of Bristol (United Kingdom); B. Heim, Univ. of Waterloo (Canada) and Max Planck Institute for the Science of Light (Germany); Z. Yan, Univ. of Waterloo (Canada) and Macquarie Univ. (Australia); H. Hübel, Univ. of Waterloo (Canada) and Stockholm Univ. (Sweden); G. Weihs, Univ. of Waterloo (Canada) and Innsbruck Univ. (Austria); E. Choi, Univ. of Waterloo (Canada); I. D'Souza, D. Hudson, COM DEV Canada (Canada); R. Laflamme, Univ. of Waterloo (Canada)

\section{QUANTUM COMMUNICATION AND QUANTUM COMPUTING WITH PHOTONS II}

8997 OC Long-distance continuous-variable quantum key distribution with advanced reconciliation of a Gaussian modulation [8997-10]

L. Gyongyosi, Budapest Univ. of Technology and Economics (Hungary) and Hungarian Academy of Sciences (Hungary); S. Imre, Budapest Univ. of Technology and Economics (Hungary) 
8997 Ol Nonmonotonic quantum-to-classical transition in multiparticle interference (Invited Paper) [8997-16]

Y.-S. Ra, Pohang Univ. of Science and Technology (Korea, Republic of); M. C. Tichy, Albert-Ludwigs-Univ. Freiburg (Germany); H.-T. Lim, O. Kwon, Pohang Univ. of Science and Technology (Korea, Republic of); F. Mintert, A. Buchleitner, Albert-Ludwigs-Univ. Freiburg

(Germany); Y.-H. Kim, Pohang Univ. of Science and Technology (Korea, Republic of)

\section{QUANTUM NONLINEAR OPTICS WITH INTEGRATED DEVICES}

$899700 \quad$ Highly mode-selective quantum frequency conversion in a slab waveguide [8997-22] M. Vasilyev, Y. B. Kwon, The Univ. of Texas at Arlington (United States); Y.-P. Huang, Northwestern Univ. (United States)

8997 OP Hybrid integration for spatially multiplexed single-photon generation [8997-35] T. Meany, Macquarie Univ. (Australia); L. A. Ngah, Lab. de Physique de la Matière Condensée, CNRS, Univ. de Nice Sophia Antipolis (France); M. J. Collins, A. S. Clark, The Univ. of Sydney (Australia); R. J. Williams, Macquarie Univ. (Australia); B. J. Eggleton, The Univ. of Sydney (Australia); M. J. Steel, M. J. Withford, Macquarie Univ. (Australia); O. Alibart, S. Tanzilli, Lab. de Physique de la Matière Condensée, CNRS, Univ. de Nice Sophia Antipolis (France)

\section{FEW-PHOTON NONLINEAR OPTICS}

8997 OR Quantum nonlinear optics using cold Rydberg atoms (Invited Paper) [8997-24] T. Peyronel, Massachusetts Institute of Technology (United States); O. Firstenberg, Harvard Univ. (United States); Q.-Y. Liang, Massachusetts Institute of Technology (United States); A. Gorshkov, Joint Quantum Institute of National Institute of Standards and Technology and Univ. of Maryland (United States); M. D. Lukin, Harvard Univ. (United States); V. Vuletic, Massachusetts Institute of Technology (United States)

\section{EXCITON-POLARITON LOGIC}

8997 OT Polariton devices and quantum fluids (Invited Paper) [8997-26]

D. Ballarini, NNL, Istituto Nanoscienze, CNR (Italy); M. De Giorgi, NNL, Istituto Nanoscienze, CNR (Italy) and Istituto Italiano di Tecnologia (Italy); G. Lerario, A. Cannavale, Istituto Italiano di Tecnologia (Italy); E. Cancellieri, A. Bramati, Lab. Kastler Brossel, École Normale Supérieure, CNRS, Univ. Pierre et Marie (France); G. Gigli, NNL, Istituto Nanoscienze, CNR (Italy), Istituto Italiano di Tecnologia (Italy), and Univ. del Salento (Italy); F. Laussy, Univ. Autónoma de Madrid (Spain); D. Sanvitto, NNL, Istituto Nanoscienze, CNR (Italy) and Istituto Italiano di Tecnologia (Italy)

8997 OU The exciton-polariton microcavity as an optical transistor (Invited Paper) [8997-27] M. Steger, D. Snoke, Univ. of Pittsburgh (United States) 
8997 OW Quantum dot spin-photon entanglement and photon-to-spin teleportation (Invited Paper) [8997-29]

W. B. Gao, P. Fallahi, E. Togan, A. Delteil, Y. S. Chin, J. Miguel-Sanchez, A. Imamoglu, ETH Zürich (Switzerland)

8997 OY Demonstration of a variable plasmonic beam splitter [8997-31]

S. Kumar, N. I. Kristiansen, U. L. Andersen, A. Huck, Technical Univ. of Denmark (Denmark)

Author Index 
Proc. of SPIE Vol. $8997899701-6$

Downloaded From: https://www.spiedigitallibrary.org/conference-proceedings-of-spie on 26 Apr 2023 Terms of Use: https://www.spiedigitallibrary.org/terms-of-use 


\section{Conference Committee}

Symposium Chairs

David L. Andrews, University of East Anglia Norwich (United Kingdom)

Alexei L. Glebov, OptiGrate Corporation (United States)

Symposium Co-chairs

Jean Emmanuel Broquin, IMEP-LAHC (France)

Shibin Jiang, AdValue Photonics, Inc. (United States)

Program Track Chair

Zameer U. Hasan, Temple University (United States)

Conference Chairs

Zameer U. Hasan, Temple University (United States)

Philip R. Hemmer, Texas A\&M University (United States)

Hwang Lee, Louisiana State University (United States)

Charles M. Santori, Hewlett-Packard Laboratories (United States)

Conference Program Committee

Dmitry Budker, University of California, Berkeley (United States)

Alan E. Craig, Montana State University (United States)

Jonathan P. Dowling, Lovisiana State University (United States)

Gurudev Dutt, University of Pittsburgh (United States)

James D. Franson, University of Maryland, Baltimore County

(United States)

Kai-Mei C. Fu, University of Washington (United States)

David H. Hughes, Air Force Research Laboratory (United States)

Fedor Jelezko, Universität Stuttgart (Germany)

Seth Lloyd, Massachusetts Institute of Technology (United States)

Marko Loncar, Harvard University (United States)

Hideo Mabuchi, Stanford University (United States)

Alan L. Migdall, National Institute of Standards and Technology (United States)

Aleksander K. Rebane, Montana State University (United States)

Matthew J. Sellars, The Australian National University (Australia)

Selim M. Shahriar, Northwestern University (United States)

Alan Eli Willner, The University of Southern California (United States)

Jörg Wrachtrup, Universität Stuttgart (Germany)

Horace P. Yuen, Northwestern University (United States)

M. Suhail Zubairy, Texas A\&M University (United States) 
1 Diamond Nanophotonics I: Joint Session with Conference 8994

Ali Adibi, Georgia Institute of Technology (United States)

2 Diamond Nanophotonics II: Joint Session with Conference 8994

Ren-Jye Shine, Massachusetts Institute of Technology (United States)

3 Nonbleaching and Ultrasmall Fluorescent Tags: Joint Session with

Conference 8956

Ramesh Raghavachari, U.S. Food and Drug Administration

(United States)

Philip R. Hemmer, Texas A\&M University (United States)

4 Quantum Communication and Quantum Computing with Photons I

Geoff J. Pryde, Griffith University (Australia)

5 Quantum Communication and Quantum Computing with Photons II

Olivier Pfister, University of Virginia (United States)

6 Quantum Communication and Quantum Computing with Photons III John C. Howell, University of Rochester (United States)

7 Quantum Imaging and Metrology

Alan L. Migdall, National Institute of Standards and Technology (United States)

8 Quantum Nonlinear Optics with Integrated Devices

Kartik Srinivasan, National Institute of Standards and Technology (United States)

9 Few-Photon Nonlinear Optics

Jason S. Pelc, Stanford University (United States)

10 Exciton-Polariton Logic

Charles Santori, Hewlett-Packard Laboratories (United States)

11 Quantum Communication with Integrated Optics

Ranojoy Bose, Hewlett-Packard Laboratories (United States) 